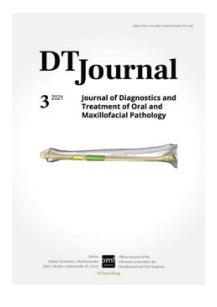

\title{
Business Articles and Section in the World Leading Jaw-Face Reconstruction Journals
}

\author{
Ivan V. Nagorniaka, \& Nataliia M. Koba ${ }^{b}$
}

To be successful, you have to have your heart in your business, and your business in your heart. - Thomas Watson, Sr., former CEO, IBM

P rivate practice in the recent years became not only an important part of the general dentistry ${ }^{1,2}$ but also the plastic surgery, ${ }^{3,4}$ facial feminization surgery $^{5}$, and oral and maxillofacial surgery (OMS) $)^{6,7}$. So the appearance of Business and Practice Management articles $^{3,4}$ indicates that surgical communities start to understand the importance of business direction not only from practical appliance but also from the scholar analysis which became extremely demanded in prepandemic and in a current pandemic era.

In 2021, the Plastic and Reconstructive SurgeryGlobal Open (PRS Global Open) journal became a role-model publication for other journals both in plastic surgery and in an oral-maxillofacial surgery due to the launch of Business section. Cat Begovic, MD from California started to lead that new cuttingedge section in PRS Global Open as a founding section editor.

Moreover, such a timely and extremely demanded

Kyiv, Ukraine

${ }^{a}$ MSc, PhD, Head Physician, Private Practice.

${ }^{b}$ MSc, Former Head Physician, Private Practice-SCIEDECE LTD.

* Corresponding author's address: Private Practice (certificate for management system according to ISO 9001:2015 - Private Entrepreneur Nagorniak I.V.), 6-G Andruschenka Street, Office 6, Kyiv 01135, Ukraine E-mail: ivan.nagorniak@gmail.com (Ivan Nagorniak) section cannot be ignored by other surgical journals, especially the publications related with Oral and Maxillofacial Surgery. That is why it can be so important for the Journal of Diagnostics and Treatment of Oral and Maxillofacial Pathology to launch the Section Business in the nearest 20212022 period. The goal of which will be to review and to publish the best manuscripts dedicated to analysis of private OMS practice sector. And the articles like "Practice management in oral and maxillofacial surgery" recently presented in the Oral and Maxillofacial Surgery Clinics of North America journal show us how the state of the art manuscripts should be prepared for that new section. ${ }^{7}$ Analysis of practice ownership forms, role of investors, accounting and tax, marketing, revenue cycle and staff management, and more others business features should be meticulously investigated in a way which will help others to follow their dream moving own private OMS practice forward.

Play by the rules, but be ferocious. -Phil Knight

Co-founder of Nike 


\section{REFERENCES}

1. Wu, KY, Wu, DT, Nguyen, TT, Tran, SD. COVID-19's impact on private practice and academic dentistry in North America. Oral Dis 2021;27( Suppl 3): 684- 7. https://doi.org/10.1111/odi.13444

2. Loretto C. The case for private practice. Am J Orthod Dentofacial Orthop 2017;151(2):243-4. . https://doi.org/10.1016/j.ajodo.2016.11.017

3. Reece EM, Tanna N, Rohrich RJ. The missing link: the business of plastic surgery. Plast Reconstr Surg 2020;146(4):905-12.

https://doi.org/10.1097/PRS.0000000000007182

4. Zarrabi B, Burce KK, Seal SM, Lifchez SD, Redett RJ, Frick KD, Dorafshar AH, Cooney CM. Business education for plastic surgeons: a systematic review, development, and implementation of a business principles curriculum in a residency program. Plast Reconstr Surg. 2017 May;139(5):1263-71. https://doi.org/10.1097/PRS.0000000000003290

5. Raffaini M, Perello R, Tremolada C, Agostini T. Evolution of full facial feminization surgery: creating the gendered face with an all-in-one procedure. $J$ Craniofac Surg 2019;30(5):1419-24.

https://doi.org/10.1097/SCS.0000000000005221

6. Zhou S. Prof. James Hupp: an academic career vs. private practice of oral and maxillofacial surgery. Front Oral Maxillofac Med 2019;1:2.

https://doi.org/10.21037/fomm.2019.06.01

7. Baker J, Leavitt A, Jundt JS. Practice management in oral and maxillofacial surgery. Oral Maxillofac Surg Clin North Am 2019;31(4):601-9.

https://doi.org/10.1016/j.coms.2019.07.004 